\title{
Low CSF pressure headache
}

\author{
SR Thanthulage* \\ Consultant in Anaesthesia and Pain Medicine, Mid Essex \\ Hospitals NHS Trust, Broomfield Hospital, Chelmsford, Essex, UK
}

*Corresponding author: subodha@btinternet.com

\begin{abstract}
Orthostatic headaches following dural puncture are well known to anaesthetists as well as other physicians who perform lumbar punctures. However, due to the progression of medical knowledge and newer diagnostic capabilities, many other causes of low pressure headaches have been recognised. Even though low pressure headache is largely underdiagnosed at present, with increased awareness it may become a common finding in the future. This article includes symptoms, diagnostic problems, and treatment options available for patients with low CSF pressure headache including post dural puncture headaches.
\end{abstract}

Keywords: low pressure headache; spontaneous; iatrogenic; intracranial hypotension; cerebrospinal fluid leak; low cerebrospinal fluid pressure.

\section{Introduction}

The normal intracranial pressure (ICP) depends infection, as the CSF leak is into a sterile on age and body posture. In a healthy adult this environment. This is unlike the CSF leak could range between $7-15 \mathrm{mmHg}$ supine to -10 to following a surgical procedure or traumatic $-15 \mathrm{mmHg}$ in vertical position. According to the injury. Causes of the leak are largely unknown Monroe- Kellie doctrine, the total intracranial but the predisposing dural weakness such as dural volumes which consist of brain, blood, CSF and or arachnoid diverticula or trivial trauma are other pathological entities such as tumours remain hypothesised as contributing factors and are fixed. ${ }^{1}$ The dynamics of ICP is maintained by commonly found in patients with connective changing volumes of blood or CSF. While tissue disorders. ${ }^{7,8}$ One of the postulated cerebral blood flow (CBF) depends on cerebral complications of weak dural tissue is possible perfusion pressure (CPP), the CSF production, CSF leak around those areas (nerve root sheath, absorption and circulation play a key role in ICP. ${ }^{2}$ epidural cyst or diverticula) due to cough, minor Normal production of CSF in an adult is around trauma or severe exercise or even dural tear $500 \mathrm{ml}$ a day and its pressure in the lumbar spine caused by a spondylitic spur. ${ }^{7,8,10,11,12}$ Anatomical could vary between -5 to- $15 \mathrm{mmHg}$ on horizontal location of the CSF leaks need to be actively and around $40 \mathrm{mmHg}$ in sitting positions. ${ }^{3}$ The investigated on a suspected patient. ${ }^{4,8,10,12}$ The most common neurologic symptom associated with CSF pressure change is headache. Low pressure headaches, which are due to low CSF pressure or volume, are increasingly implicated as a cause of daily persistent headache. ${ }^{1,2,3,4}$ Low pressure headache could be provoked (following lumbar puncture or breaching of the dura following a neurosurgical procedure) or spontaneous (CSF leak). Low pressure headache without any clear provocation is termed as spontaneous intracranial hypotension $(\mathrm{SIH}){ }^{5,6,7}$

Causes of spontaneous and iatrogenic CSF leak (Box 1)

Spontaneous CSF leak generally neither present with any local symptoms nor carry any risk of

commonest anatomical sites are at the cervicothoracic junction or at the thoracic spine. The skull base is the least common place to have CSF leaks. ${ }^{8,10,11}$

Iatrogenic CSF leaks in anaesthetic practice mainly occur following lumbar puncture or neurosurgical interventions.

\section{The anatomy and pathophysiology of low pressure headaches}

The spinal dura mater starts at the foramen magnum and can extend up to the lower limit of S2 which consist of dense connective tissue matrix of collagen. Nevertheless there are tight fibrous connective tissues being identified connecting the posterior spinal dura at the atlanto 
-axial and atlanto-occiptal levels to nuchal ligament. ${ }^{6,13,14}$

Box 1: Potential risks factors for low CSF pressure headaches ${ }^{7,8}$

\begin{tabular}{|c|c|}
\hline $\begin{array}{l}\text { Risk factors for spontaneous } \\
\text { CSF Leak }\end{array}$ & $\begin{array}{l}\text { Risk factors for iatrogenic (lumbar } \\
\text { puncture) CSF leak }\end{array}$ \\
\hline $\begin{array}{l}\text { Marfan Syndrome } \\
\text { Ehlers-Danlos Syndrome } \\
\text { Autosomal dominant } \\
\text { polycystic kidney disease } \\
\text { Isolated joint hypermobility } \\
\text { Isolated skeletal features of } \\
\text { Marfan syndrome } \\
\text { Joint hyper mobility with } \\
\text { facial thinning } \\
\text { Spontaneous retinal } \\
\text { detachment }\end{array}$ & $\begin{array}{l}\text { Age 18-40 } \\
\text { Female sex } \\
\text { Low BMI } \\
\text { History of chronic headaches } \\
\text { Size of the needle } \\
\text { Shape of the needle } \\
\text { Bevel orientation } \\
\text { Failure to replace stylet before } \\
\text { removal of the spinal needle } \\
\text { Poor hydration }\end{array}$ \\
\hline
\end{tabular}

The pathophysiology of the disease was first described by Augustus Bier in the 1890s as being due to a CSF leak. The pain generators of the low pressure headache are not entirely certain. The best theoretical explanation is, that the imbalance between the CSF leak through the dural defect and the production, give rise to depletion of CSF volume. Firstly this will generate reflex vasodilation of pain sensitive cerebral vessels to compensate intra cranial volumes; secondly there will be traction on pain sensitive meninges and cranial and spinal nerves. Furthermore another causative factor of headache is neuronal hypersensitivity to substance $\mathrm{P}$ which is released in high quantities in up to $30 \%$ of the dural puncture patients.

\section{Clinical presentation and diagnosis of low CSF pressure headache ${ }^{10}$}

The commonest clinical presentation in low CSF pressure headache is orthostatic headache which occurs or worsens within 15 minutes on upright position and improves within 30min of 'lying down' or within 3 days of epidural blood patches, although this could be variable. ${ }^{7,8}$ Iatrogenic low CSF pressure headaches are followed by the event and $66 \%$ to $90 \%$ dural puncture related CSF leaks become symptomatic in 2 to 3 days respectively. ${ }^{7}$ Onset of spontaneous CSF leak headaches could be abrupt or sub-acute, reaching maximum intensity overtime or may be very vague and become apparent over time. ${ }^{10-15}$ Typically the pain locations are frontal $\left(5^{\text {th }}\right.$ cranial) occipital, temporal $\left(9^{\text {th }}\right.$ and $10^{\text {th }}$ cranial) neck and shoulders $(\mathrm{C} 1,2,3){ }^{8,9}$
Description of headache may be throbbing, or non-throbbing, pulling the head toward the neck, feeling of an ice cube in an empty glass and it is rarely unilateral. ${ }^{4,8}$ Although postural headache is the hallmark of low CSF pressure headache, in untreated patients the posture related component may become less prominent. Headache may become lingering and persistent and unrelated to posture or completely absent. ${ }^{7,8,12,15}$ The most common accompanying symptoms according to literature reports are nausea, neck stiffness and photophobia which suggest meningeal irritation. The symptoms such as tinnitus and hyperacusis (extreme aversion and hypersensitivity to sounds) or hypoacusia (slightly diminished acuteness of the sense of hearing) with a sense of losing balance are associated with irritation of $8^{\text {th }}$ intra cranial nerve complex. ${ }^{4,8,9,12,15}$ An ophthalmological symptom such as diplopia after spinal anaesthesia was described by Augustus Bier for the first time $100 \mathrm{yrs}$ ago. The ophthalmological effects such as visual blurring or visual field defect and diplopia are due to the effects on $2^{\text {nd }}, 3^{\text {rd }}, 4^{\text {th }}$ and $6^{\text {th }}$ cranial nerves. The common and rare clinical manifestations of CSF leak in otherwise healthy adults are summarised in Box 2. Subtle cognitive changes may fail to be recognised until the successful treatment of the CSF leak. Spinal manifestation of the CSF leak can be shoulder, inter scapular pain, radicular symptoms or local back pain at the site of the injections. ${ }^{8,9,12,15}$

As with any other disease, diagnosis should start with listening to the patient's history and a thorough examination. Low pressure nature could be easily missed as the presentation symptoms could be vague, especially in spontaneous CSF leak, however such patients may also present with acute symptoms. ${ }^{16}$ Although $90 \%$ of PDPH patients present within first 3 days, presentation could be delayed up to 12 days or if untreated headache can remain with long term CSF leak. ${ }^{17}$, $18,19,20$ 
Box 2: Common and rare clinical manifestation of CSF leaks ${ }^{10,15}$ (These symptoms have been reflected in the International Headache Society (IHS) Diagnostic Criteria (Box 3) caused by low ICP. ${ }^{4,5,8}$ )

\begin{tabular}{l} 
Common symptoms \\
Headache \\
Neck stiffness or pain (meningeal irritations) \\
Shoulder and interscapular pain ( traction on cervical 123 nerve roots) \\
Nausea with or without vomiting \\
Altered hearing ( Echoed, distant noise, muffled noise) \\
Disturbed sense of balance or dizziness \\
Photophobia (meningeal irritations) \\
Visual blurring (11,111, IV,Vl, cranial nerves palsy) \\
Horizontal diplopia (unilateral or bilateral cranial nerve VI palsy) \\
Uncommon \\
Non horizontal diplopia (cranial nerve 111 or $1 \mathrm{~V}$ palsy) \\
Encephalopathy, obtundation, coma, stupor \\
Visual field defects \\
Upper limb numbness, weakness or spasm \\
Menieres syndrome like symptoms (labyrinthine hydrops ) \\
Fronto-temporal dementia \\
Parkinsonism, ataxia, bulbar manifestations \\
Dorsal mid brain syndrome \\
Unsteady gait \\
Bladder and bowel control difficulties \\
Quadriplegia \\
Chorea \\
Decrease growth hormone secretion, galactorrhoea (due to the distortion of \\
pituitary gland) \\
Amnesia \\
Psychic akinesia (hypoactive hypo alert behaviour) \\
Transtentorial herniation \\
Acute respiratory failure \\
Cerebella haemorrhages \\
\hline
\end{tabular}

If the clinical diagnosis of CSF leak has been suspected, radiological investigation and diagnostic studies will greatly facilitate the confirmation of the cause as well as its anatomical location.

Magnetic Resonance Imaging (MRI) has greatly improved the understanding of the features of intracranial hypotension as well as reduces the time needed to confirm the diagnosis. (Figure 1) On the other hand poor understanding of the MRI changes or variable findings, may prevent the patient been diagnosed with low pressure headache. Diagnostic studies and typical features seen are summarised in Box 4.
Box 3: IHS Diagnostic criteria caused by low CSF pressure headaches ${ }^{4,5}$

\begin{tabular}{|c|c|c|c|}
\hline Criteria & $\begin{array}{l}\text { Post-dural } \\
\text { puncture } \\
\text { headache } \\
\text { Diagnostic } \\
\text { criteria }\end{array}$ & $\begin{array}{l}\text { CSF fistula } \\
\text { headache }\end{array}$ & $\begin{array}{l}\text { Headache } \\
\text { attributed to } \\
\text { spontaneous (or } \\
\text { idiopathic) low } \\
\text { CSF pressure }\end{array}$ \\
\hline$A$ & $\begin{array}{l}\text { neck stiffness } \\
\text { tinnitus } \\
\text { hypoacusia } \\
\text { photophobia } \\
\text { nausea }\end{array}$ & $\begin{array}{l}\text { neck stiffness } \\
\text { tinnitus } \\
\text { hypoacusia } \\
\text { photophobia } \\
\text { nausea }\end{array}$ & $\begin{array}{l}\text { neck stiffness } \\
\text { tinnitus } \\
\text { hypoacusia } \\
\text { photophobia } \\
\text { nausea }\end{array}$ \\
\hline B & $\begin{array}{l}\text { Dural puncture } \\
\text { has been } \\
\text { performed }\end{array}$ & $\begin{array}{l}\text { A known } \\
\text { procedure or } \\
\text { trauma has } \\
\text { caused persistent } \\
\text { CSF leakage with } \\
\text { at least one of the } \\
\text { following: } \\
\text { 1. evidence of low } \\
\text { CSF pressure on } \\
\text { MRI (e.g., } \\
\text { pachymeningeal } \\
\text { enhancement) } \\
\text { 2.evidence of CSF } \\
\text { leakage on } \\
\text { conventional } \\
\text { myelography, CT } \\
\text { myelography or } \\
\text { cisternography } \\
3 . \text { CSF opening } \\
\text { pressure }<60 \text { mm } \\
\mathrm{H}_{2} \mathrm{O} \text { in sitting } \\
\text { position }\end{array}$ & $\begin{array}{l}\text { 1. evidence of low } \\
\text { CSF pressure on } \\
\text { MRI (e.g., } \\
\text { pachymeningeal } \\
\text { enhancement) } \\
\text { 2. evidence of CSF } \\
\text { leakage on } \\
\text { conventional } \\
\text { myelography, CT } \\
\text { myelography or } \\
\text { cisternography } \\
\text { 3. CSF opening } \\
\text { pressure <60 mm } \\
\mathrm{H}_{2} \mathrm{O} \text { in sitting } \\
\text { position }\end{array}$ \\
\hline$C$ & $\begin{array}{l}\text { Headache } \\
\text { develops within } \\
5 \text { days after } \\
\text { dural puncture }\end{array}$ & $\begin{array}{l}\text { Headache } \\
\text { develops in close } \\
\text { temporal relation } \\
\text { to CSF leakage }\end{array}$ & $\begin{array}{l}\text { No history of dural } \\
\text { puncture or other } \\
\text { cause of CSF } \\
\text { fistula }\end{array}$ \\
\hline D & $\begin{array}{l}\text { Headache } \\
\text { resolves either } \\
\text { spontaneously } \\
\text { within } 1 \text { week } \\
\text { within } 48 \text { hours } \\
\text { after effective } \\
\text { treatment of the } \\
\text { spinal fluid leak } \\
\text { (usually by } \\
\text { epidural blood } \\
\text { patch) }\end{array}$ & $\begin{array}{l}\text { Headache } \\
\text { resolves within } 7 \\
\text { days of sealing } \\
\text { the CSF leak }\end{array}$ & $\begin{array}{l}\text { Headache resolves } \\
\text { within } 72 \text { hours } \\
\text { after epidural blood } \\
\text { patching }\end{array}$ \\
\hline $\begin{array}{l}\text { Confir } \\
\text { matio } \\
\mathrm{n} \text { of } \\
\text { the } \\
\text { diagn } \\
\text { osis }\end{array}$ & $\begin{array}{l}\text { Headache that } \\
\text { worsens within } \\
15 \text { minutes after } \\
\text { sitting or } \\
\text { standing and } \\
\text { improves within } \\
15 \text { minutes after } \\
\text { lying, with at } \\
\text { least one of the } \\
\text { Criteria A and } \\
\text { fulfilling } \\
\text { criteria C and } \\
\text { D }\end{array}$ & $\begin{array}{l}\text { Headache that } \\
\text { worsens within } 15 \\
\text { minutes after } \\
\text { sitting or standing, } \\
\text { with at least one } \\
\text { of the Criteria A } \\
\text { and fulfilling } \\
\text { criteria C and D }\end{array}$ & $\begin{array}{l}\text { Diffuse and/or } \\
\text { dull headache that } \\
\text { worsens within } 15 \\
\text { minutes after sitting } \\
\text { or standing, with at } \\
\text { least one of the } \\
\text { Criteria A and } \\
\text { fulfilling criterion } \\
\text { D }\end{array}$ \\
\hline
\end{tabular}


Box 4: Diagnostic studies

\begin{tabular}{|c|c|c|}
\hline $\begin{array}{l}\text { Diagnostic } \\
\text { study }\end{array}$ & Findings & Remarks \\
\hline MRI & $\begin{array}{l}\text { Subdural collections, } \\
\text { Pachymeningeal } \\
\text { enhancement } \\
\text { Engorgement of } \\
\text { venous structures } \\
\text { Pituitary } \\
\text { hyperaemia, } \\
\text { Sagging of the brain }\end{array}$ & $\begin{array}{l}\text { Pachymeningeal } \\
\text { enhancement is the most } \\
\text { well documented } \\
\text { abnormality, could be } \\
\text { identify as diffuse, non- } \\
\text { nodular enhancement in } \\
\text { supra and infratentorial } \\
\text { compartments. } \\
\text { Nevertheless around } 20 \% \text { of } \\
\text { the patient this may be } \\
\text { negative. } \\
\text { Improvement of MRI } \\
\text { changes could identify within } \\
\text { days to weeks of the } \\
\text { successful treatment for the } \\
\text { CSF leak. Patient who does } \\
\text { not have specific treatment } \\
\text { may still have the MRI } \\
\text { changes despite their } \\
\text { clinical improvements. }\end{array}$ \\
\hline $\begin{array}{l}\text { Cranial } \\
\text { computed } \\
\text { tomography }\end{array}$ & $\begin{array}{l}\text { Subdural fluid } \\
\text { collections } \\
\text { Obliteration of } \\
\text { subarachnoid } \\
\text { cisterns and } \\
\text { ventricular collapse }\end{array}$ & $\begin{array}{l}\text { May not be conclusive but } \\
\text { has a diagnostic value in } \\
\text { emergency department } \\
\text { setting. }\end{array}$ \\
\hline Myelography & $\begin{array}{l}\text { Location of the leak } \\
\text { Extent of the leak, } \\
\text { Meningeal } \\
\text { diverticula }\end{array}$ & $\begin{array}{l}\text { In combination with } \\
\text { enhanced MRI thin cut } \\
\text { myelography allows most } \\
\text { accurately identify the leak } \\
\text { in the entire spine. } \\
\text { Fear of cerebral herniation } \\
\text { due to the myelography not } \\
\text { yet documented and risks } \\
\text { exacerbation of existing } \\
\text { symptoms are around } 5 \% \text {. }\end{array}$ \\
\hline $\begin{array}{l}\text { Radinucletidec } \\
\text { ysternography }\end{array}$ & $\begin{array}{l}\text { Early accumulation } \\
\text { of tracer in kidneys } \\
\text { and bladder } \\
\text { Slow ascent along } \\
\text { the spinal axis } \\
\text { Paucity of activity } \\
\text { over the cerebral } \\
\text { convexities } \\
\text { Parathecal activity at } \\
\text { the level } \\
\text { or approximate site } \\
\text { of leak }\end{array}$ & $\begin{array}{l}\text { This remains useful when } \\
\text { the diagnosis of CSF leak in } \\
\text { doubt with normal } \\
\text { myelography results. } \\
\text { May not show exact site of } \\
\text { the leak and may remained } \\
\text { incomprehensible in one } \\
\text { third of patients. }\end{array}$ \\
\hline Spinal MRI & $\begin{array}{l}\text { Dilated epidural and } \\
\text { intra dural veins } \\
\text { Dural enhancement } \\
\text { Meningeal } \\
\text { diverticular } \\
\text { Nerve root sleeve } \\
\text { ectasia } \\
\text { Extrathecal CSF } \\
\text { collections } \\
\text { Syringomyelia } \\
\text { Retrospinal fluid } \\
\text { collections. }\end{array}$ & $\begin{array}{l}\text { In the presence of extradural } \\
\text { fluid will helpful to identify } \\
\text { the location of the leak, but } \\
\text { this is very rare to be } \\
\text { effective. }\end{array}$ \\
\hline $\begin{array}{l}\text { Lumbar } \\
\text { puncture and } \\
\text { CSF opening } \\
\text { pressure } \\
\text { measurements }\end{array}$ & $\begin{array}{l}\text { Low CSF pressure } \\
\text { (less than } 60 \mathrm{~mm} \\
\text { water) }\end{array}$ & Can be persistently normal \\
\hline CSF analysis & $\begin{array}{l}\text { Lymphocytic } \\
\text { pleocytosis } \\
\text { Normal or elevated } \\
\text { proteins content up } \\
\text { to } 1000 \mathrm{mg} / \mathrm{dl} \\
\text { Xanthochromia }\end{array}$ & $\begin{array}{l}\text { CSF appearance may be } \\
\text { normal, xanthochromia is } \\
\text { probably due to increased } \\
\text { permeability of dilated } \\
\text { venous complexes but it } \\
\text { could be due to blood tap. }\end{array}$ \\
\hline
\end{tabular}

If the clinical diagnosis of CSF leak has been suspected, radiological investigation and diagnostic studies will greatly facilitate the confirmation of the cause as well as its anatomical location.

Magnetic Resonance Imaging (MRI) has greatly improved the understanding of the features of intracranial hypotension as well as reduces the time needed to confirm the diagnosis. (Figure 1) On the other hand poor understanding of the MRI changes or variable findings, may prevent the patient been diagnosed with low pressure headache. Diagnostic studies and typical features seen are summarised in Box 4.

Figure 1: Diagnostic investigations in CSF leaks
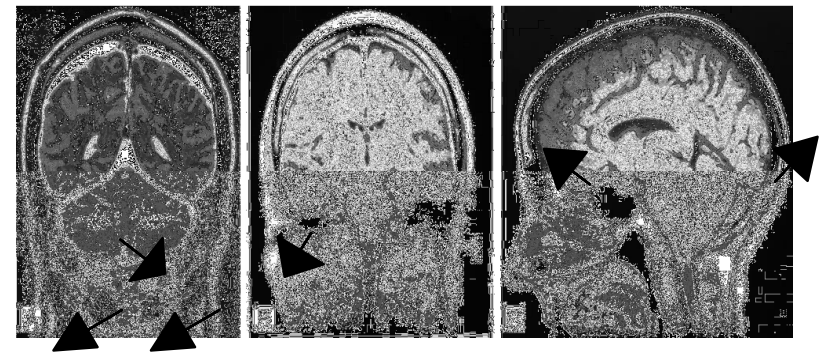

A, Brain MR images showing typical findings in spontaneous intracranial hypotension with a coronal T2-weighted image showing subdural fluid collections; $B$, a coronal gadoliniumenhanced T1-weighted image showing enhancement of the pachymeninges; and $C$, a T1weighted sagittal image showing sagging of the brain ${ }^{4}$ (Published with permission of Professor W.I. Schievink)

\section{Incidence and differential diagnosis (Box 5)}

Low pressure headaches associated with spontaneous intracranial hypotension and fistula leaks are rare (5 in 100,000 , female to male ratio $1: 2)$. On the other hand incidence in post dural puncture headache (PDPH) is not uncommon and could vary $(10-30 \%){ }^{2,8,20,21,22}$ 
Box 5: Differential diagnosis in low pressure headaches $8,17,20$

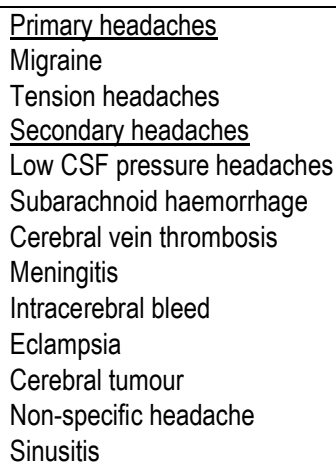

Treatment

Although there are several methods of treatment available for low CSF pressure headaches most of the iatrogenic and spontaneous CSF leaks resolve spontaneously with bed rest and hydration. Symptoms of PDPH may improve within one week, but duration for resolution of spontaneous leaks is unknown. ${ }^{7,8,11}$

\section{Conservative treatment}

Patients who seek medical treatment should initially be treated with conservative methods. The key is to reassure the patient and provide emotional support, bed rest, regular analgesics and hydration. Even though bed rest has been advocated it can only postpone the headache in some PDPH patients. Oral and intravenous hydration remain key to avoid dehydration, as poor hydration is associated with headaches, although it has not shown to increase the CSF production. ${ }^{7,8,9}$

\section{Caffeine}

Effect of caffeine is due to cerebral vasoconstriction and stimulating the CSF production. Intravenous injection of caffeine may be 70 to $80 \%$ effective in the initial stage of the treatment of PDPH, but unfortunately headache may return after 48 hours. $^{7,9,11}$

\section{Theophylline}

As with caffeine intravenous theophylline causes cerebral vasoconstriction.

\section{Adrenocorticotropic hormones}

Steroid hormones act by stimulating adrenal gland to increase CSF production and endorphin release, and can be used to treat low CSF pressure headaches.
Epidural saline and colloid infusions

These methods only produce transient effect due to increase in epidural pressure thereby reducing the CSF leak temporarily.

Autologous epidural blood patch (ABP)

In the event of failure to respond to conservative treatment using a targeted epidural blood patch should be considered. The main stay of treatment of CSF leak with autologous epidural blood (ABP) patch was first described by Gromeley in $1960 .^{21}$ Pain relief is usually instantaneous and this often confirms the diagnosis. The mechanism of pain relief is firstly associated with the immediate dural tamponade effect and secondly with sealing of the dural leak. The success rate of persistent pain relief in PDPH could vary between 61 to $95 \%$. Most recommended blood volumes are 15 to $20 \mathrm{ml}$ for the $1^{\text {st }}$ blood patch. A second ABP will be able to relieve symptoms in almost all patients. ${ }^{7}$ On the other hand in spontaneous intracranial hypotension, ABP may help only up to $30 \%$ of the patients. ${ }^{7,8}$ The discrepancy is likely to be due to the fact that spontaneous leaks could also be in the anterior aspect of the dura, the dural sleeves or could be due to multiple leaks. Furthermore dural holes may be complicated with weak unsupported subarachnoid tissues. In the event of multiple leaks, targeted multiple limited EBP could be performed at multiple sites. ${ }^{11}$

If the $1^{\text {st }} \mathrm{ABP}$ is not effective the second blood patch with up to $100 \mathrm{ml}$ could be injected within 5 days interval. The volume of blood could be restricted due to high risk of infection with large volumes as well as back and radicular pain. ${ }^{8,22}$

\section{Other techniques}

If epidural blood patching fails to reduce pain, placement of percutaneous fibrin sealant should be performed. Surgical repair should be left as the last resort for patients who are refractory to all other methods of treatment. Surgical repair of the CSF leaks are safe and can provide long lasting relief but this needs knowledge of the precise anatomical location of the leak. Accurate diagnosis and treatment of the low CSF pressure headache has very good prognosis of long lasting relief with less than $10 \%$ of recurrence in spontaneous CSF leaks. ${ }^{8}$

In conclusion, low CSF pressure headaches while not a life threatening condition may cause considerable lowering of the quality of life.

Iatrogenic causes of low CSF pressure headaches are well recognised and measures to reduce it should be undertaken. Spontaneous intracranial 
hypotension often remains under diagnosed. The spectrum of clinical and radiographic manifestations is varied, with diagnosis largely based on clinical suspicion, cranial magnetic resonance imaging, and myelography. Numerous treatment options are available, but much remains to be learned about this disorder.

\section{Acknowledgments}

The author wishes to thank Drs. P Tilakaratna, S Liyanage and VN Rathnasiri, for their valuable suggestions and editing of this review.

\section{References}

1. Steiner LA, Andrews PJD. Monitoring the injured brain: ICP and CBF. British Journal of Anaesthesia 2006;97(1):26-38

http://dx.doi.org/10.1093/bja/ael110 PMid: 16698860

2. Sun-Edelstein C, Lay CL. Headache attributed to spontaneous intracranial hypotension, treatment and prognosis. www.uptodate.com

3. Turnbull DK, Shepherd DB. Post-Dural puncture headache: pathogenesis, prevention and treatment. British Journal of Anaesthesia 2003;91 (5):718-29 http://dx.doi.org/10.1093/bja/aeg231

4. Schievink WI. Diagnostic Criteria for Spontaneous Spinal CSF Leaks and Intracranial Hypotension. AJNR Am J Neuroradiol 2008;29:853-56 http://dx.doi.org/10.3174/ajnr.A0956 PMid: 18258706

5. Headache Classification committee for the IHS The International Classification of Headache Disorders, 3rd edition (beta version) Cephalalgia 2013; 33(9): 629-808

6. Frank RL. Lumbar Puncture and Post-Dural Puncture Headaches: Implications for the Emergency Physician. The Journal of Emergency Medicine 2008;35(2):149-157 http://dx.doi.org/10.1016/j.jemermed.2007.03.024 PMid: 17976786

7. LeepHunderfund AN, Mokri B. Orthostatic Headache with and without Cerebrospinal Fluid Leak: A Review. European Neurological Jounal 2009; 1: (1) 1-11

8. Schievink WI. Spontaneous Spinal Cerebrospinal Fluid Leaks and Intracranial Hypotension JAMA, 2006; 295(19): 2286-2296

9. Ghaleb A. Post dural Puncture Headache. Anesthesiology Research and Practice Volume 2010, Article ID 102967, 6

10. Mokri B. Cerebrospinal Fluid Volume Depletion and Its Emerging Clinical/Imaging Syndromes. Neurosurg Focus 2000;9(1) http://dx.doi.org/10.3171/foc.2000.9.1.6

11. Kim SY. Epidural Blood Patches in a Patient with Multi-level Cerebrospinal Fluid Leakage That Was Induced by Spontaneous Intracranial Hypotension. Korean J Pain 2010; 23: $46-50$ http://dx.doi.org/10.3344/kjp.2010.23.1.46

PMid:20552073 PMCid:PMC2884212

12. Park E, Kim E. Spontaneous Intracranial Hypotension: Clinical Presentation, Imaging Features and Treatment. J Korean NeurosurgSoc 2009;45: 1

http://dx.doi.org/10.3340/jkns.2009.45.1.1

PMid:19242563 PMCid:PMC2640824

13. Zheng N, Yuan X-Y, Li Y-F et al. Definition of the To Be Named Ligament and Vertebrodural Ligament and Their Possible Effects on the Circulation of CSF. PLoS ONE 9(8): e103451. doi:10.1371/journal.pone.0103451 http://dx.doi.org/10.1371/journal.pone.0103451

14. Cilliers A, Schulenberg DH, van Rensburg JJ, Gen D. et al. MRI determination of the vertebral termination of the dural sac tip in a South African population: clinical significance during spinal irradiation and caudal anaesthesia. South African Journal of Radiology 2010; 14 (3):52-55.

15. Wicklund MR, Mokri B. Frontotemporal brain sagging syndrome: an SIH-like presentation mimicking FTD. Neurology 2011 Apr 19;76(16):1377-82

http://dx.doi.org/10.1212/WNL.0b013e3182166e42 PMid:21502595 PMCid:PMC3087405

16. Vaidhyanath R, Kenningham R et al. Spontaneous intracranial hypotension: a cause of severe acute headache. www.emjonline.com

17. Reamy BV. Post-Epidural Headache: How Late Can It Occur. JABFM 2009; March-April: Vol 22 No. 2

18. Scott S, Davenport R. Low pressure caused by spontaneous intracranial hypotension. $B M J$ 2014;349;35-38

http://dx.doi.org/10.1136/bmj.g6219

PMid:25378383

19. Kadrie H, Driedger AA, Mcinnis W. Persistent Dural Cerebrospinal Fluid Leak Shown by Retrograde Radionuclide Myelography: Case Report J Nuci Med 1976 sep;17(9): 797-799

20. Thomas R, Thanthulage S. Intracranial hypotension headache after uncomplicated caudal epidural injection Anaesthesia. 2012 Apr;67(4):416-9. http://dx.doi.org/10.1111/j.13652044.2011.06980.x PMid:22288890

21. Gaukroger PB, Brownridge P. Epidural blood patch in the treatment spontaneous low CSF pressure headache. Pain 1987;29:119-122 http://dx.doi.org/10.1016/0304-3959(87)90185-0

22. Desai MJ, Dave AP, Martin MB. Delayed Radicular Pain Following Two Large Volume Epidural Blood Patches for Post-Lumbar Puncture Headache: A Case Report. Pain Physician 2010;13:257-262. PMid:20495590 